\title{
“EVERYBODY SHOULD WITNESS OUR HAPPINESS": MATRIMONIAL SHOWS ON TURKISH TELEVISION CHANNELS
}

\author{
Erdem Güven ${ }^{1}$ \\ İlkay Kanık
}

\begin{abstract}
In every culture and society, rituals of marriage are changing depending on different traditions and customs. Modernization and the developments in the mass media, naturally changed or at least made these customs and traditions compatible with the changing situation. In Turkish culture, the first step of the arranged (family-initiated) marriages - asking a family to give their daughters as a bride (kız isteme)- is more invisible and "between the members of the two families" (aile arasında). Kız isteme ritual is also an important phase in the love marriages. Approbation of family and the society is important not only in arranged marriages, but also in love marriages.

Although, the ceremony is mostly invisible and between the members of the families of the bride and the groom, it became an important "subject of rumor" especially among women. Neighbors of the bride and the groom and relatives always eager to learn the details about the groom and bride, as well as about the ceremony itself. Today, matrimonial shows on Turkish televisions arose from this curiosity and turning it into cash. At those matrimonial shows such as Esra Erol'da Evlen Benimle (Marry me at Esra Erol Show), Su Gibi (Pure as Water) and Ne Çıkarsa Bahtına (By Chance), candidates give information about themselves, express their criteria about marriage and trying to find their spouses in public, on television. If they get along with each other, their wedding ceremony also holds live on TV screens. As Andy Warhol predicted, every couple became famous at least for 15 minutes at those shows whether they got married or not.

In this research, we will try to explain how the customs and traditions did become compatible with mass media and how mass media and its rules did changed those customs and traditions. We will use discourse analysis method in order to explain the subject.
\end{abstract}

Keywords: Matrimonial shows, Fame, Marriage, Television programs in Turkey

1 Assistant Professor, Kastamonu University, Turkey, [eguven@kastamonu.edu.tr]

2 Assistant Professor, Beykent University, Turkey. 


\title{
“HERKES MUTLULUĞUMUZA ŞAHIT OLMALI": TÜRK TELEVIZYON KANALLARINDA EVLILIKK PROGRAMLARI
}

\begin{abstract}
ÖZ
Her toplumda evlilik eylemi farklı ritüellere sahiptir ve bu eylem farklı gelenek ve adetlere bağlıdır. Modernleşmenin etkisi ve kitle iletişim araçlarının gelişimiyle beraber bu gelenek ve adetlerin bazıları ortadan kalkmış, değişim göstermiş ya da değişen durumla uyumlu hale gelmiştir. Türkiye'de görücü usulü evliliklerin ilk adımı olarak kabul edilen kız isteme seremonisinin daha "görünmez" daha doğrusu "iki aile arasında" olduğunu görmekteyiz. Ancak, görücü usulünden farklı bir evlilik türü olan aşk evliliklerinde bile, kız isteme seremonisi genellikle mevcuttur. Ailelerin onayı, her iki evlilikte de önem arz eden bir faktördür. Her ne kadar kız isteme seremonisi çoğunlukla "görünmez" ya da aileler arasında gerçekleşen bir uygulama olsa da, özellikle kadınlar arasında "dedikodu konusu"dur. Komşular ve seremonide bulunamayan uzak akrabalar, gelin ya da damat adayı, veya seremoni akşamı hakkında bilgi sahibi olmak isterler. Türk televizyonlarındaki evlilik programları, bu merakın nakde çevrilebileceği düşüncesiyle ortaya çıkmışlardır. Esra Erol'da Evlen Benimle, Su Gibi ve Ne Çıkarsa Bahtına gibi programlarda adaylar, herkesin gözü önünde evlilik isteklerini beyan etmekte, evlilik seremonisi de dahil evliliğe dair merak edilen tüm aşamalar, televizyon izleyicisinin gözlerinin önünde cereyan etmektedir. Andy Warhol'ün de öngördüğü gibi bu çiftler, evlenseler de evlenmeseler de "en az 15 dakikalığına ünlü" olmaktadırlar.

Bu çalışmada örf ve adetlerin günümüz kitle iletişim araçlarıyla nasıl uyumlu hale getirildiği ya da kitle iletişim araçlarının ve onun kurallarının bu örf ve adetleri nasıl değişikliğe uğrattı̆̆ı, evlilik programları üzerinden incelenecektir.
\end{abstract}

Anahtar Kelimeler: İzdivaç programları, Şöhret, Evlilik, Türkiye’de Televizyon Programları

\section{History of Dating Shows on the World and on Turkish Televisions: A Historical and}

\section{Theoretical Introduction}

According to Jonathan Roberti, the average adult in America watches 4 hours of programming a day. Watching television is an activity that influences its viewers in many ways including their consumption habits, sexual development etc. starting in early childhood (Roberti, 117). When we look at the Social Cognitive Theory that Bandura states, we can see that the "televised models may teach or remind viewers of appropriate norms or standards for interpersonal conduct in particular contexts". With the help of this theory, we can understand that the viewers are not only "passive audiences" but they are also cognizant consumers "who reflect, regulate and vicariously learn from the material projected on television". (Ferris et al., 491). Dating shows also teaches many things to their consumers about sexual or romantic relationship. 


\section{BUJSS}

9/1 (2016), 102-117

Cultivation Theory which is developed by George Gerbner and his colleagues also states that "viewers, over time attend the messages and images found on television that symbolize a standardized representation of the world". (Ferris et al., 492). According to that theory, heavy viewers of television starts to think that the real world is like the one presented on television. Those kinds of viewers are more likely believe to the lives that they couldn't have a chance to experience (Yaylagül, 75).

Dating show format in the world emerged in the 1960s with two programs named The Dating Game and Love Connection. Both of them aimed to send the contestant on a date for to make a romantic connection. When the producers detected the success and the popularity of the format, they decided to air new derivations of this kind such as The Bachelor, The Bachelorette, Change of Heart, A Dating Story, Dismissed, Elimi-DATE, Extreme Dating, The Fifth Wheel, For Love or Money, Friends or Lovers, Joe Millionaire, The Last Resort, Love Cruise, Marry My Mom, Married By America, Meet My Folks, Mister Personality, Rendez-View, Perfect Partner, Shipmates, Single in L.A., Speed Dating, Star Dates, Taildaters, and Temptation Island. The most important difference between the current dating shows and their predecessors in America is the boost of sexuality rather than romantic connection. Sexuality became the major focus of the shows after the year 2000 (Roberti, 118-119). MTV's dating shows have changed the meaning of dating and thoughts of the American youth about relationships. Singled Out, which was aired in 1995 on MTV was trying to emphasize sexual relationship or one night stand rather than romantic connection or marriage. According to Benjamin Solomon, Singled Out "is also notable for featuring gay and lesbian contestants, a rarity at the time, but something they would continue on almost all of their future dating shows". The effects of those kinds of dating shows can be seen in modern culture in accordance with the technology, with applications like OkCupid and Tinder which gives opportunity for men and women who are seeking a relationship that hinges on sexuality (Solomon, 2013).

As we have mentioned before with the words of Andy Warhol stating that "in the future, everyone will be world-famous for fifteen minutes" is becoming true with those kinds of reality dating shows or other kinds of programs. According to Graeme Turner, the contemporary celebrity is emerged especially from the sports or entertainment industries but the modern celebrity has no need for a special achievement in sports, arts or any other business. Attraction of public attention is enough for being a celebrity. Turner gives the example of the contestants on Big Brother and Survivor who gained the prominence for short and intense periods (Turner, 3). With those kinds of reality shows "ordinary people" gets the chance to be famous like the "real celebrities" who they saw on TV. Dating shows and the matrimonial shows also gave hope to those "ordinary people" to be a "famous couple" at least for a short period. 


\section{BUJSS}

9/1 (2016), 102-117

With those motivations, dating shows in Turkey started with the emergence of the privately-owned television channels in the mid-1990s. Turkish people met with many different kinds of entertainment programs along with the erotic shows or programs that were based on men and women relationship. Before 1990s there was a single channel which was in control of the state. On state owned TRT (Turkish Radio and Television) those kinds of programs were not welcomed. In August 4th 1990 the first privately-owned channel of Turkey, Star 1 was established and started to broadcast. This important development on broadcasting structure became an irrevocable milestone for Turkish televisions. As Gözde Demirel (158) mentioned, emergence of the first private channel Star 1 "gave birth to the duality between TRT and the private channels. This distinction was also reflected in the broadcasting policy". TRT was selective and employed the official artists and musicians with a high level of music education as civil servants. As Soydan (65) stated, arabesque music was prohibited by TRT on account to the fact that it gives rise to cultural degeneration. In contrast to this manner, private channels chose to show Arabesque and popular music programs. They also employed many people who are not professional artists but can be popular with their physical appearances like handsome/beautiful models. "This popularism is increased in Turkey in the period 1970-1980 because of the military coups” as Şebnem Soygüder stated. Although Soygüder explains this period (the period after the repressive military environment) as "liberation period" (89), this kind of popularism was supported by the governments who were the products of the military coups. Because they knew that with the help of "tabloidization" process, the masses can be hypnotized more easily. We must see the private channels and their format as the success of the governments who were trying to grow "apolitical generations".

The first dating show called Saklambaç (Hide and Seek) was broadcasted in another privately-owned channel, Show TV in 1994. The program's format was simple. One man was asking some questions about relationship, life and their hobbies to the three girls who were behind a curtain or vice versa. The man or the girl cannot see the girls or the boys but the audience could see them all. When he selects the girl that he approves, the announcer of the program sends the couple to a romantic dinner with a limousine. This romantic dinner with wine glasses, roses and a limousine reflects the "romantic utopia" which was already created by the mass media itself (movies, TV shows exc.).

Hide and Seek became the catalyst for those kinds of shows and especially the matrimonial shows which are very popular today. Famous TV stars and singers presented this program. The announcer and the nominees were mostly talking about sexuality. The main goal of the program was to entertain the TV audience. The audience never learns the ending of the meeting or never sees the couple again after the "romantic dinner". 


\section{BUJSS}

9/1 (2016), 102-117

\section{Mass Medium and the Changing Concept of Marriage}

The first matrimonial show on Turkish televisions started to broadcast at November 12th 2007 on Flash TV. Flash TV is famous with its cheap-budget entertainment programs and shows. Although the channels audience profile is mostly undereducated, matrimonial show concept and its nowadays famous announcer Esra Erol is liked very much by many people who are in different educational and social status. The program started to broadcast at a more popular channel, A TV, due to its successful progress. Its format is different from the dating shows which were broadcasted in 1990's. Those programs are especially cheap-budget productions just like the dating shows. The producers do not have to pay high fees to the professional star actors and this reduces the production costs of the show. The audience can have the chance to see "people like themselves" in those kinds of reality shows and those shows serve as the "talk of the day" for the viewers. Motti Neiger identifies those dating shows as "reality shows" which takes the advantage of the viewers' desire for "voyeurism". Those reality shows have spread all over the world, through the influence of American cultural industries (Neiger, 124). Although this genre is an example of Globalization and Americanization in general, the formats of the shows could have changed through country to country. Matrimonial shows on Turkish televisions are unique and suitable to the Turkish culture.

With the increasing conservatism trend in Turkey, especially after Justice and Development Party came to power in 2002, many things were started to change in Turkish media and in the country itself. First of all, the owners of television channels have changed and this process is going on even today. More conservative television channel owners and entrepreneurs took over the most important and popular channels in Turkey. Broadcasting policies of those television channels have also changed with the changing situation and appropriate to the conservatism trend. Many journalists and important media professionals whose opinions and ideologies were not in accordance with the ruling party's ideology got sacked from the television channels and newspapers which were in control of these new entrepreneurs.

In Turkey, American style dating shows also changed their format and became matrimonial shows, in which the main target became "marriage with the permission of God" (Allah'ın emri ile evlenmek) rather than flirting. However vice Prime Minister Bulent Arinc evaluated those matrimonial shows as "Scandal" and "against the women's rights" (Haber 7 Web Sitesi, 2012).

As Althusser states, media itself serves as one of the ideological state apparatus. Those apparatuses such as media, family, religion, education and law, political and cultural institutions are functional in production and reproduction of the ideology. According to Tebrike Kaya (83), matrimonial shows are trying to make contact with the social culture and the dominant ideology in accordance with Althusser's point of view. 


\section{BUJSS}

9/1 (2016), 102-117

Although the context and the format changed, the main goal stays the same: "To entertain people with programs which cost small amounts of money and to earn more with advertisements". As we have mentioned before, the most important purpose of those shows were to give the audience what they want: "People like themselves, people like their neighbors on the TV screen".

Before the matrimonial shows, there were many other programs that seem "suitable" to the Turkish culture and family values. Gelinim olur musun? (Would you be my daughter-in-law?), was an important example to those kinds of programs. In this show, intended brides were trying to endear themselves to the mothers of the intended grooms. In Turkey, the relationship between the mother-in-law and daughter-in-law is the main subject of gossip in every family. Producers saw this curiosity and created a show about this relationship. Semra Kaynana (Semra the mother-in-law) became a famous and "wicked" figure that represents the mother who was trying to control the relationship between her son and the girl which he loves. At the end of this reality show, Semra Kaynana does not give permission to this marriage and in real life her son Ata commits a suicide because of the suppression. After this event, the format of the program has been criticized very much and although the son of Semra Kaynana died, she became a popular TV star and an advisor about a healthy marriage.

The relationship between matrimony and media in Turkey starts with the dating columns in newspapers. At those columns, applicants were giving information about themselves, their physical appearance and character; also specifying their criteria and writing / sending poems in order to find a suitable spouse by using nicknames. This kind of dating was popular in 1970's and 80's in Turkey when there was no internet connection and private-owned channels. There were also advice columns in newspapers one of which and most famous was known as the column of Güzin Abla (Sister Güzin). Nowadays, the daughter of Güzin Abla is writing her comments about marriage and giving advices to the couples at Hürriyet newspaper by using the same column name. In those advice columns, the advisors who were known as reliable and sophisticated women were sharing their experience about a happy marriage.

Internet became another important mass medium for marriage and dating nowadays. It is possible to shop for your new home, complete a course or find a love relationship without in person contact with people. But we have to know that, cyberspace is not virtual. Online relationships are also conducted between flesh and blood people. As Aaron Ben-Zeev mentions, cyberspace is part of real space and online relationships are real relationships (Ben-Zeev, 2). Today, future marital partners can be found, and even sexual desires can be fulfilled on the internet. Online dating is a way of communication in order to develop a romantic or sexual relationship between two people. According to statistics, online dating business is the third largest revenue 


\section{BUJSS}

9/1 (2016), 102-117

producer behind filmed entertainment and digital music and the "revenues for this industry are expected to grow by \%10 through 2013 (Mitchell (a), 2009). Robert L. Mitchell describes the internet dating sites as "the love machines of the Web" and also as big business (Mitchell (b), 2009). Online dating has become such a mainstream activity that, there are hundreds of online dating sites today. According to Terry Ulick and Alyssa Wodtke, online dating sites are big stores with lots of products in it (Ulick\&Wodtke, 23). When we look at the statistics about online dating, we can see that in the United States, 37 percent of all single internet users looking for a partner have visited an internet dating site.

As a growing industry, there are many opinions about online dating sites or online dating process itself. According to some researchers, online dating does not have the same dynamics as face-to-face relationships, meaningful and successful relationships cannot be formed in cyberspace. However, others think that cyberspace is a place that can liberate the interpersonal relationship. Internet dating can be a chance for individuals, who may have difficulty in forming face-to-face relationships (Kang \& Hoffman, 206).

In those sites, users indicate their age, gender, educational level, physical appearance and their income. They also indicate why they joined the site (for a long-term relationship or for a "casual" relationship) (Hitsch et al., 135). Religious belief can be an important factor for dating or marriage for many people. The general idea for those religious dating sites is to encourage marriage and dating within the same faith. Christian and Jewish dating sites are very popular in cyberspace. In Turkey, there are many Muslim dating and matrimonial sites such as gonuldensevenler.com, nasipse.com, islamievlilik.com and inchallah.com.

\section{Arranged Marriage in Turkish Culture}

Act of marriage generally concerns the two people who love or who get along with each other. The decision about marriage is made by those two people in order to start a family. However, the cultural factors that change from country to country naturally affect the marriage act. In non-Western cultures, we can see extended family type and dependence to family values. In Turkish culture, individuals generally are bounded strictly to the Turkish family values and traditions. The parents' opinions and satisfaction about marriage decision of their children is very important in Turkish culture.

According to some researchers, in the Iranian, Chinese and Indian societies, where the traditional values are decisive, men especially pay importance to honesty, virtue and honor (namus) of the women along with cooking and motherhood ability. In Muslim cultures, arranged marriage is seen as a way to preserve the honor of family (Litton-Fox, 182). According to Nermin Abadan's research about marriage in Turkey which was conducted in 1967 , majority of male respondents would refuse to marry a girl who "had had a friendship with a person of the opposite sex" (Abadan, 92) because of the suspicion of her loss of virginity 


\section{BUJSS}

9/1 (2016), 102-117

which is very important in non-Western societies. On the other hand, women are trying to find a man, who has a high level of income and social status. In traditional societies, decision of the family about those subjects can be very important (Çimen, 55).

In contrast to love marriages, arranged marriages are highly intervened by families via their selection of suitable marriage partner. According to Batabyal, arranged marriages have been around for several centuries and they are the rule of society in many parts of Africa, Asia and Middle East rather than an exception. We can see arranged marriages mostly among pre-industrial societies in order to create and preserve alliances between the extended families. According to some researchers, more than half of the existing marriages are (\%56) in Turkey are family-initiated or arranged marriages. Nevertheless, love matches or marriages are found more often among the more "modernized" segments of the population. Nermin Hortaçsu states that, romantic love marriages were first appeared in Turkish urban metropolis at the end of 19th century (Gündoğdu-Aktürk, 28-29). Batabyal and Beladi describe love marriages as "Western style" and the arranged marriages as "Eastern style". However, they emphasize the importance of globalization and education. According to Batabyal and Beladi, with the increasing mobility of people across the world, former Westerners become Easterners and former Easterners become Westerners. Also, "general rise in the education of women in the East has resulted in a breakdown of traditional barriers between Eastern-style arranged marriages and Western-style love marriage" (Batabyal \& Beladi, 893). Today we can mostly see a hybrid form of love-marriage and arranged-marriage in Turkey.

Table 1- Decision for marriage by sex

\begin{tabular}{|c|c|c|}
\hline \multicolumn{3}{|c|}{ Decision for marriage by sex (2006) } \\
\hline Turkey & Female & Male \\
\hline $\begin{array}{l}\text { Arranged Marriage (Decision of my family) } \\
\text { Arranged Marriage (My Decision) } \\
\text { My choice, family approval } \\
\text { Without approval and information of family } \\
\text { My decision, family not informed } \\
\text { Married in spite of the family's rejection } \\
\text { According to strict traditional rules }\end{array}$ & $\begin{array}{c}36.2 \\
28.0 \\
27.4 \\
6.1 \\
1.5 \\
0.6 \\
0.1\end{array}$ & $\begin{array}{c}24.8 \\
31.9 \\
35.2 \\
5.7 \\
1.8 \\
0.6 \\
0.1\end{array}$ \\
\hline Urban (Turkey) & Female & Male \\
\hline $\begin{array}{l}\text { Arranged Marriage (Decision of my family) } \\
\text { Arranged Marriage (My Decision) } \\
\text { My choice, family approval } \\
\text { Without approval and information of family } \\
\text { My decision, family not informed } \\
\text { Married in spite of the family's rejection } \\
\text { According to strict traditional rules }\end{array}$ & $\begin{array}{c}31.9 \\
31.5 \\
28.8 \\
6.1 \\
1.7 \\
0.8 \\
0.1 \\
\end{array}$ & $\begin{array}{c}22.5 \\
39.3 \\
30.9 \\
4.6 \\
1.9 \\
0.8 \\
0.1 \\
\end{array}$ \\
\hline $\begin{array}{l}\text { Rural (Turkey) } \\
\end{array}$ & Female & Male \\
\hline $\begin{array}{l}\text { Arranged Marriage (Decision of my family) } \\
\text { Arranged Marriage (My Decision) } \\
\text { My choice, family approval } \\
\text { Without approval and information of family } \\
\text { My decision, family not informed } \\
\text { Married in spite of the family's rejection } \\
\text { According to strict traditional rules }\end{array}$ & $\begin{array}{c}43.5 \\
26.6 \\
20.5 \\
1.2 \\
7.8 \\
0.3 \\
0.1\end{array}$ & $\begin{array}{c}28.6 \\
33.3 \\
28.6 \\
1.6 \\
7.4 \\
0.4 \\
0.1\end{array}$ \\
\hline
\end{tabular}

Table-1: Türkiye İstatistik Kurumu Web Sitesi, 2006. 


\section{BUJSS}

9/1 (2016), 102-117

In order to understand the marriage forms in Turkey we have to look at the statistics. According to Family Structure Survey that was conducted in 2006 by Turkish Statistics Institute, 36.2 percent of women and 24.8 percent of men decided to marry by arranged marriage procedure and with the decision of their family. In rural areas this increases to 43.5 percent for women and 28.6 percent for men. However the rates decrease to 31.9 percent for women and 22.5 percent for men. Another form of marriage is again arranged marriage but the last decision belongs to the couple. 28 percent of women and 31.9 percent of men are married with this method in Turkey (Türkiye İstatistik Kurumu Web Sitesi, 2006).

As we can clearly see through the table, 64.2 percent of the women and 56.7 percent of men preferred arranged marriage or have to choose a spouse with the decision of their families. Family approval is very important in Turkey in any case (Türkiye İstatistik Kurumu Web Sitesi, 2006).

In Turkish Statistics Institute's survey for dating style of spouses according to their educational level in 2006, we can see a distinct difference between the non-literate ones and postgraduates. 96.8 percent of non-literates find their spouses by suggestion of their families or their neighbors. However this rate decreases to 47.5 percent for bachelor degrees. They mostly find their spouses at their school, entourage, or at their workplaces (51.2 percent). Nevertheless, 0.3 percent of the bachelor degrees use internet and dating agencies for dating.

Table 2- Dating style according to Educational Status

\begin{tabular}{|l|c|c|c|c|c|c|}
\hline $\begin{array}{l}\text { Dating style according to } \\
\text { Educational status (2006) }\end{array}$ & $\begin{array}{l}\text { Family } \\
\text { \&Neighbors }\end{array}$ & At School & At Work & Entourage & $\begin{array}{l}\text { Internet\& } \\
\text { Dating } \\
\text { Agency }\end{array}$ & Other \\
\hline Non-Literate & 96.8 & 0.2 & 0.4 & 1.9 & 0 & 0.7 \\
Literate & 94.7 & 0.3 & 3.3 & 3.3 & 0 & 0.7 \\
Primary school & 89.8 & 0.9 & 2.8 & 5.8 & 0 & 0.7 \\
Secondary school & 79.5 & 3.1 & 6 & 9.6 & 0.2 & 1.7 \\
High-school & 66.2 & 5.4 & 13.5 & 13.8 & 0.1 & 1 \\
University and higher & 47.5 & 13.9 & 15.3 & 22 & 0.3 & 1 \\
\end{tabular}

Table-2. Türkiye İstatistik Kurumu Web Sitesi, 2006.

As we can see clearly, most of the individuals in Turkey prefer to find their spouses with the suggestion of their families and neighbors. Although this rate decreases with raising educational level, the suggestion of family and neighbors is still very important among the high-school and university graduates. 


\section{Televised Dating and Marriage on Turkish Televisions: Example of Esra Erol'da Evlen Benimle (Marry Me at Esra Erol Show)}

As we have mentioned before, in Turkish traditions kız isteme ceremony is "between families". Outsiders or the distant relatives of the intended groom and bride are not invited to this ceremony. The intended groom and his parents visit to the girls' house with a box of chocolate or Turkish delight and flowers. First, the intended bride makes a Turkish coffee to the visitors. The father and the mother of the intended groom see the girl while she serves coffee to them. Father or an elder relative of the intended groom wants the intended bride from her father for his son by saying “Allah'nn emri, peygamberin kavli ile..." meaning that "by order of God and with the words of Prophet Muhammad". If the father of the intended bride and the girl herself approve the marriage, the offering is accepted and k1z isteme ceremony will be finished. After this ceremony, in many parts of Turkey, söz kesme (promise ceremony), nişan (engagement ceremony), kına gecesi (henna night), dini nikah (religious ceremony) and resmi nikah (civil marriage ceremony) are held.

At Esra Erol'da Evlen Benimle (Marry me at Esra Erol Show), there is a different kind of ritual from traditional kız isteme ceremony. Women or men, who intended to participate the show for marriage, first apply the program via telephone or internet. They can also seek their spouses after they saw the man or the woman that they like on TV. The first step of the show can be seen as the presentation or making an appearance part for the nominees. In this part of the show, participators present themselves; specify their criteria for marriage and ideal spouse and also indicate their social, marital and economic status. If both of the participators accept to meet with each other, the participator who is attracted by the nominee who was already on TV screen is invited to the show with the financial support of the producers of the program.

The second step of the show starts after the arrival of the nominee in the studio. In this part of the show, the announcer Esra Erol makes an appearance. She leads the show and the audience at the studio. While the two nominees asking each other questions behind the curtain, she and the audience comments and evaluates the relationship and the nominees. The announcer Esra Erol works also as the matchmaker. The comments of the frequenter participators are very important for the show because they are also seen as the members of the family. Those comments of the "family members" and the matchmaking process of Esra Erol makes the program itself reliable in the eyes of the nominees and the audience who are watching this show on their televisions. Esra Erol and the "reliable" frequenter participators are just like the "elders of the family" in the arranged marriage. 


\section{BUJSS}

9/1 (2016), 102-117

In the arranged marriage, kiz isteme ceremony is generally held in the biggest and the most important living room of the house (in Turkish its called misafir odası or salon, a room where the guests are welcomed). Matrimonial shows and also our example "Marry me at Esra Erol Show" brings this living room to the homes of the TV audience. TV studio became a simulated model of this special room. As we have mentioned before, the curiosity for this ceremony in Turkey makes this program popular for many people, especially for housewives.

In this second step of the show, the nominees introduce themselves like they are stage actors. They sing songs or recite poems in order to describe themselves. We can't see those kinds of activities in the real arranged marriages or in kiz isteme ceremonies. On the contrary, especially in kiz isteme ceremonies, the intended groom and bride keep silent and answer the questions when the elders ask them. However in matrimonial shows, by performing they have chance to become popular and they can also became a frequenter participator in the show. This performance of the nominees is also the climax point and the most entertaining part of the program.

After this performance, the curtain is lifted slowly with a music which is aimed to excite the audience and have two potential endings. The nominee accepts the meeting in private or rejects the man or woman who wants to marry with him or herself. If the nominee accepts the offer, he or she says "Lets drink a cup of tea together" and the announcer Esra Erol sends the couple to a private room that the audience can see but can't hear, in order to give them a chance to know each other better. Although they are in private space, they are not out of sight and their gestures can be seen and controlled by the audience. This process has similarities with the söz kesme process in the arranged marriage. In arranged marriages, promise ceremony (söz kesme) legalizes the dating of the two people and after that ceremony they can meet without any restrictions but in control of the family members.

In those kinds of programs and in Marry me at Esra Erol Show, main target is to excite and to make the TV audience curious about the ending. Therefore, the last decision of the nominees is always postponed by the announcer in order to keep this curiosity alive. This curiosity means more advertisements and more money for the TV professionals. However, in the traditional kiz isteme ceremony, the decision of the families and the couple is announced as soon as possible.

In the last step of the program, last decision of the nominees is announced. If the couple decided to marry, the process goes on with the wedding ceremony that is held on live TV show. Especially the matchmaker and the announcer of the program Esra Erol became one of the witnesses of the marriage. Here we have to mention that, the announcer herself was married on TV at her program. By broadcasting her 


\section{BUJSS}

9/1 (2016), 102-117

marriage live at the program, the producers aimed to strengthen the reliability of the show. The psychologists and the lawyers, who play an important role at the show with their comments, also help this strengthening effect.

According to Esra Erol, Marry me at Esra Erol Show, serves as a program which aims to unite the right people with each other. By touching on the life stories of different people and with the help of the experts (psychologists and lawyers), the program also tries to give a lesson to its audience about life. Erol also mentioned that the nominees prefer this program because of its reliability. According to Erol they trust the show and the announcer, because everything in the show is overt and broadcasted live on TV. "Nowadays the trust is vanished in relationships. In order not to be disappointed in their relationship, the nominees decide to find their spouses in our show" says Esra Erol (Interview with Esra Erol's assistant Yağmur Gönültaş via internet, 05.07.2013).

6.786 nominees applied the show from 2007 to 2013, 3810 were men and 2976 were women and more than 250 couples were married on TV. Also in the other matrimonial show, Su Gibi (Pure as Water), 275 couples were married in six years. Many of those nominees have attended the program with the approval and advice of their families, close friends and relatives. According to Erol, this approval is very important for her. 35 percent of the nominees are between 25-35 years old and most of them never married before. However when we look at the statistics, 54 percent of the nominees were once had a marriage and 41 percent is bachelors. According to statistics of Cozum Statistic Institute, 34.8 percent of the participators have primary education and 62 percent of them are graduated from a college or university. (Interview with Esra Erol's assistant Yağmur Gönültaş via internet, 05.07.2013) Most of the participators are trying to find a spouse who is wealthy or have good economic condition, sociable, and who don't have bad habits such as drinking alcohol. They are also trying to find spouses who have "fear of God" and "who have faith".

\section{CONCLUSION}

In Turkey, arranged marriage is still preferred by many people who are trying to find a suitable spouse for marriage. As we have mentioned before, arranged marriages are seen mostly in extended families and the marriage of their daughters and sons is very important for the families because of the "family honor". Arranged marriage is seen as a way to protect the family honor for many people in Turkey and in Muslim countries.

Elders of the family and the parents of the intended groom and bride play an important role in those kinds of marriages. Also in the matrimonial shows such as Marry me at Esra Erol Show we can see the family image clearly. Approval of the participators and audience of the show became a kind of family approval. 


\section{BUJSS}

9/1 (2016), 102-117

As Esra Erol states, the audience and nominees also evaluated as "part of the family". This imaginary "family image" strengthens the reliability of the show in the eyes of the audience. This can be seen as a simulated model of kiz isteme ceremony in the arranged marriage. Nevertheless, this reliability differ the dating shows from matrimonial shows.

Although the format of those matrimonial shows is influenced by globalization and Americanization, in order to be accepted by the Turkish audience, the TV professionals use the traditional values and norms such as family honor and religion in the show rather than sexuality. "Gossip" and "curiosity" about marriage and relationship between intended grooms and brides are also used by those professionals by broadcasting a matrimonial show and by giving the audience a chance to "peek" a relationship between a man and a woman. The participators also became a kind of celebrity, as long as they are on TV. Their wedding ceremony is broadcasted on TV and they got married in front of the Turkish audience. 


\section{BUJSS}

9/1 (2016), 102-117

\section{REFERENCES}

ABADAN, N. (1967). “Turkey”, Women in the Modern World, Ed. R. Patai, New York: Free Press. BATABYAL, A.A. \& BELADI, H (2010). Arranged or love marriage? That is the question, Applied Economic Letters, 9:13, 893-897.

BEN-ZEEV, A. (2004). Love Online: Emotions on the Internet, New York: Cambridge University Press. ÇİMEN, E. (2007). Görücü Usulü ve Anlaşarak Evlenen Bireylerin Çeşitli Sosyal Psikolojik Faktörler Yönünden Karşılaştırılması, Unpublished Masters Thesis, Ankara Universitesi.

DEMIREL, G (2011). New Marriage Trend in Turkey: Screen Marriage, Quaderns de la Mediterrania, No.15, 157-162.

FERRIS, A.L. et al (2007). "The Content of Reality Dating Shows and Viewer Perceptions of Dating”, Journal of Communication, No. 57, 490-510.

GÜNDOĞDU-AKTÜRK, E. (2010). Attachment Figure Transference, Caregiving Styles and Marital Satisfaction in Arranged and Love Marriages, Unpublished Masters Thesis, Middle East Technical University.

HITSCH, G.J., HORTAÇSU, A. \& ARIELY, D. (2010). Matching and Sorting in Online Dating, The American Economic Review, 100:1, 130-163.

KANG, T. \& HOFFMAN, L.H (2011). Why Would You Decide to Use an Online Dating Site? Factors That Lead to Online Dating, Communication Research Reports, 28:3, 205-213.

KAYA, T. (2013). Televizyonda Yayınlanan İzdivaç Programlarında Toplumsal Cinsiyetin Temsili, Kadın Araştırmaları Dergisi, 13, 81-110.

LITTON-FOX, G. (1975). Love Match and Arranged Marriage in a Modernizing Nation: Mate Selection in Ankara, Turkey, Journal of Marriage and Family, 37:1, 180-193.

MITCHELL, R.L. (a) (2009). “Online Dating: Its Bigger than Porn”, http: // blogs.computerworld.com/online_dating_its_bigger_than_porn. (Access Date: 07.11.2015).

MITCHELL, R.L. (b) (2009). “Online Dating: The Technology Behind the Attraction”,http://www.computerworld.com/s/article/9127711/Online_dating_The_technology_behind_the_attraction. (Access Date: 07.11.2015).

NEIGER, M. (2010). "Real Love Has No Boundaries? Dating Reality TV Shows between Global Format and Local-Cultural Conflicts", Reality Television: Merging the Global and the Local, Ed. Amir Hetsroni, Nova Science Publishers, pp. 123-136. 


\section{BUJSS}

9/1 (2016), 102-117

ROBERTI, J.W. (2007). Demographic Characteristics and Motives of Individuals Viewing Reality Dating Shows", The Communication Review, 10, 117-134.

SOLOMON, B. (2013). “A Complete History of MTV's Dating Game Shows”, http://www.thedatereport.com/dating/pop-culture/a-complete-history-of-mtvs-dating-game-shows/, 2013. (Access Date: 05.03.2016).

SOYDAN, E (2015). Televizyonun arabesk müziğin soylulaşmasındaki rolü, Marmara İletişim Dergisi, 23, $61-73$

SOYGÜDER, Ş. (2003). Eyvah Paparazzi, İstanbul: Om Yayınevi.

TURNER, G. (2004). Understanding Celebrity, London: Sage Publications.

ULICK, T. \& WODTKE, A. (2005). Truth, Lies and Online Dating: Secrets to Finding Romance on the Internet, Boston: Thomson Course Technology.

YAYLAGUL, L. (2013). Kitle İletişim Kuramları: Egemen ve Eleştirel Yaklaşımlar, Ankara: Dipnot Yayınlar1.

Türkiye İstatistik Kurumu Web Sitesi, http:/tuikapp.tuik.gov.tr/aileyapidagitimapp/ aileyapi.zul, (Access Date: 07.11.2015).

Haber 7 Web Sitesi, “Arınç, evlilik programları için "rezalet” dedi” (2012). http://www.haber7.com /guncel/haber/963477-arinc-evlilik-programlari-icin-rezalet-dedi, (Access Date: 07.11.2015). Interview with Esra Erol's assistant Yağmur Gönültaş via internet, (05.07.2013). 